\title{
Research on the Technique Types of 20 UFC Champions
}

\author{
Hu Zurong \\ Department of Physical Education, Nanchang University, Nanchang 330031
}

\begin{abstract}
Through the analysis of technique types of 20 UFC champions, the result shows that the champions embody a wide variety of fighting techniques. UFC champions who have won maximum times have a variety of different types of technique style; wrestling, Brazilian jiu-jitsu, boxing, Muay Thai, karate and taekwondo champion are the fighting techniques which are relatively more involved in the training of UFC.
\end{abstract}

Keywords: UFC champion; technique type; MMA

\section{Introduction}

\subsection{Status and Trends}

MMA (Mixed Martial Arts) is a match where players of boxing, judo and wrestling, karate, etc. compete with each other. MMA has gradually become a final development of world class fighting tournament. About the study on MMA, when researching China Knowledge Resource Integrated Database, only Analysis of Technology Utilization in 2011 Ultimate Fighting Competition [1], Research on Winning Strategy for Chinese Martial Athletes in K-1 Tournament ${ }^{[2]}$, Comparison and Contrast of Sports Culture of Chinese Sanda and American MMA ${ }^{[3]}$, Study On Chinese Sanda Athletes Start Training of "Other Fighting Projects ${ }^{[4]}$ and the Comparison and Contrast Re- search on Chinese Martial Arts and American Ultimate Fighting Techniques ${ }^{[5]}$ and several other monographs have been found. Others, such as $M M A, K-1^{[6]}$, $M M A, U F C{ }^{[7]}, M M A, K-O N E$ and other Professional Events ${ }^{[8]}$, MMA Events ${ }^{[9]}$ are only mentioned by words, no special studies.

To sum up, MMA has got the attention of Chinese scholars, but still the studies on MMA and other world combat sports is lacking. In view that the development of Chinese martial arts is not so smooth and MMA is going to sweep the world, the researches on MMA and other world fighting matches are bound to be strengthened.

\subsection{Research Significance}

UFC (Ultimate Fighting Championship), coming from the U.S., is now the MMA's top events. UFC champions are from many countries and are all top players of many fighting factions who has a unique career characteristics, which has an important role in raising the level of Chinese players and enlightening the development of Chinese martial arts. In the world Sanda competition, the Chinese Sanda results are seriously threatened; in international fighting competitions, it's almost hard to find a Chinese player on the scene. UFC champion training characteristics can be an important reference when selecting, training Chinese player and during their competitions. This paper studies the technology types of champions of international top competitions UFC fighting. On 
the one hand provide relating theory of international MMA; on the other hand provide a new perspective for the study of China's martial arts development.

\section{Methods}

\subsection{Literature Method}

We have downloaded more than 60 journal articles, dissertations and newspaper articles from China Knowledge Resource Integrated Database about "UFC", "MMA", " Sanda ", " mixed martial arts " and others; have searched UFC champion information in Baidu Encyclopedia, Wikipedia and other websites; have downloaded UFC champions information over the years from UFC China website (http://www.ufc-1.com/), UFC MMA championship website (http://sports.sohu.com/ufc/) and other fighting sports website.

\subsection{Mathematical Statistics Method}

About the information of UFC champion, many domestic and foreign websites have different levels of description, such as Baidu Encyclopedia, Wikipedia, etc., differences exist between these resources and Wikipedia are relatively more authoritative and more comprehensive. After a serious discussion within group members and consulting the views of experts and scholars, we select the information from Wikipedia. On July 6, 2011, selected those who have won at least two championships from 2000 to 2010 in List of UFC Champions ${ }^{[10]}$ (including defending champion) as the objects, totally 20 . Analyze the data of technique types of the 20 UFC champions from Wikipedia to explore the relating rules.

\section{Results}

\subsection{Selection of 20 UFC champion}

This essay selected Anderson Silva, Andrei Arlovski, BJ Penn, Brock Lesnar, Chuck Liddell, Frank Mir, Frankie Edgar, Georges St-Pierre, Jens Pulver, Kevin Randleman, Lyoto Machida, Matt Hughes, Murilo Bustamante, Pat Miletich, Quinton Jackson, Randy Couture, Rich Franklin, Sean Sherk, Tim Sylvia and Tito Ortiz(see Table 1) as the main objects. Table 1 List of 20 UFC Champions Basics Information

\begin{tabular}{|c|c|}
\hline NAME & TECHNIQUE TYPE \\
\hline $\begin{array}{l}\text { Anderson } \\
\text { Silva }\end{array}$ & $\begin{array}{l}\text { Muay Thai, Boxing, Brazilian Jiu- } \\
\text { Jitsu, Taekwondo, Judo, Capoeira }\end{array}$ \\
\hline $\begin{array}{l}\text { Andrei Ar- } \\
\text { lovski }\end{array}$ & $\begin{array}{l}\text { Kickboxing, Sambo, Brazilian Jiu- } \\
\text { Jitsu }\end{array}$ \\
\hline B.J. Penn & Brazilian Jiu-Jitsu, Boxing \\
\hline Brock Lesnar & Wrestling, Submission Wrestling \\
\hline $\begin{array}{l}\text { Chuck Lid- } \\
\text { dell }\end{array}$ & $\begin{array}{l}\text { Kenpō Karate, Koei-Kan Karate, } \\
\text { Kickboxing, Wrestling }\end{array}$ \\
\hline Frank Mir & $\begin{array}{l}\text { Brazilian Jiu-Jitsu, Muay Thai, Box- } \\
\text { ing, Kenpō Karate, Wrestling }\end{array}$ \\
\hline Frankie Edgar & $\begin{array}{l}\text { Wrestling, Boxing, Brazilian Jiu-Jitsu, } \\
\text { Muay Thai }\end{array}$ \\
\hline $\begin{array}{l}\text { Georges St- } \\
\text { Pierre }\end{array}$ & $\begin{array}{l}\text { Kyokushin, Muay Thai,Boxing, Wres- } \\
\text { tling,Brazilian Jiu-Jitsu, Gaidojutsu }\end{array}$ \\
\hline Jens Pulver & Boxing, Wrestling \\
\hline $\begin{array}{l}\text { Kevin } \\
\text { Randleman }\end{array}$ & Freestyle Wrestling, Brazilian Jiu-Jitsu \\
\hline $\begin{array}{l}\text { Lyoto } \\
\text { Machida }\end{array}$ & $\begin{array}{l}\text { Machida Karate, Shotokan Karate, } \\
\text { Brazilian Jiu-Jitsu }\end{array}$ \\
\hline Matt Hughes & $\begin{array}{l}\text { Wrestling, Submission Grappling, } \\
\text { Boxing }\end{array}$ \\
\hline $\begin{array}{l}\text { Murilo } \\
\text { Bustamante }\end{array}$ & Brazilian Jiu-Jitsu \\
\hline Pat Miletich & $\begin{array}{l}\text { Brazilian Jiu-Jitsu, Karate, Boxing, } \\
\text { Muay Thai, Wrestling, Freestyle } \\
\text { Fighting }\end{array}$ \\
\hline $\begin{array}{l}\text { Quinton Jack- } \\
\text { son }\end{array}$ & Wrestling, Boxing, Muay Thai \\
\hline $\begin{array}{l}\text { Randy Cou- } \\
\text { ture }\end{array}$ & $\begin{array}{l}\text { Greco-Roman Wrestling, Boxing, } \\
\text { Muay Thai, Catch Wrestling }\end{array}$ \\
\hline Rich Franklin & $\begin{array}{l}\text { Boxing, Kickboxing, Muay Thai, Bra- } \\
\text { zilian Jiu-Jitsu }\end{array}$ \\
\hline Sean Sherk & Wrestling, Brazilian Jiu-Jitsu, Boxing \\
\hline Tim Sylvia & Kickboxing, Brazilian Jiu Jitsu \\
\hline Tito Ortiz & Wrestling, Kickboxing \\
\hline
\end{tabular}


era; as for their performance, several champions included have won more than five times. Besides that, there are also some cross-level champions like Anderson Silva, Chuck Liddell, Matt Hughes and Randy Couture, etc. who have won UFC 5-8 times. BJ Penn and Randy Couture are the only two players who have won two levels competition.

\subsection{Technique Styles of 20 UFC Champions}

Herein we define the term "technique style" as the equal meaning of "technique species", such as sanda, taekwondo, boxing, wrestling, Muay Thai and judo.

According to calculation, the 20 UFC champions have been taught totally 67 kinds of techniques, an average of 3.35 kinds per person, that is, everyone have received the professional training of more than three kinds of fighting techniques. Four of them have got the training of more than five kinds (Table 2).

Table 2 UFC Champions learn more than Five Kinds of Technique Species

\begin{tabular}{|c|c|c|}
\hline NAME & TECHNIQUE SPECIES & TOTAL \\
\hline $\begin{array}{l}\text { Anderson } \\
\text { Silva }\end{array}$ & $\begin{array}{l}\text { Muay Thai, Boxing, Bra- } \\
\text { zilian Jiu-Jitsu,Taekwondo, } \\
\text { Judo, Capoeira } \\
\text { Kyokushin,Muay }\end{array}$ & 6 \\
\hline $\begin{array}{l}\text { Georges } \\
\text { St-Pierre }\end{array}$ & $\begin{array}{l}\text { Thai,Boxing, } \\
\text { tling,Brazilian } \\
\text { Gaidojutsu }\end{array}$ & 6 \\
\hline $\begin{array}{l}\text { Pat Milet- } \\
\text { ich }\end{array}$ & $\begin{array}{l}\text { Brazilian Jiu-Jitsu, Karate, } \\
\text { Boxing, Muay Thai, Wres- } \\
\text { tling, Freestyle Fighting }\end{array}$ & 6 \\
\hline Frank Mir & $\begin{array}{l}\text { Brazilian Jiu-Jitsu, Muay } \\
\text { Thai, Boxing, Kenpō Kara- } \\
\text { te, Wrestling }\end{array}$ & 5 \\
\hline
\end{tabular}

Table 2 shows that, Anderson Silva, Georges St-Pierre and Pat Miletich obtain the most kinds of technique species. For example, Anderson Silva has received the professional training of Muay Thai, boxing, Brazilian jiu-jitsu, taekwondo, judo and Brazilian Capoeira; Georges StPierre has experienced the training of karate, Muay Thai, boxing, wrestling, Brazilian jiu-jitsu and Greg surgery . Thus we can draw a conclusion that UFC champion usually is skilled at a variety of fighting techniques, and these fighting techniques are combined together on the basis of mutual complementary thus creating a good player .

\subsection{The Connection between Cham- pionship and Technique Style}

To find out the relationship between championship and technique style, we analyzed the technique style of 20 UFC champions, including four players who have won (defending champion involved) champion 8 times or more, namely, Randy Couture, Matt Hughes, Anderson Silva and Georges St-Pierre. The former two have won nine championships and the latter two have won eight championships. (Table 3)

Table3 Technique Style of Players Won 8 Times or More

\begin{tabular}{|c|c|c|c|}
\hline NAME & $\begin{array}{l}\text { WINNING } \\
\text { TIMES }\end{array}$ & $\begin{array}{l}\text { TECHNIQUE } \\
\text { STYLE }\end{array}$ & TOTAL \\
\hline $\begin{array}{l}\text { Randy } \\
\text { Couture }\end{array}$ & 9 & $\begin{array}{l}\text { Greco-Roman } \\
\text { Wrestling, Boxing, } \\
\text { Muay Thai, Catch } \\
\text { Wrestling }\end{array}$ & 4 kinds \\
\hline $\begin{array}{l}\text { Matt } \\
\text { Hughes }\end{array}$ & 9 & $\begin{array}{l}\text { Wrestling, Submis- } \\
\text { sion Grappling, } \\
\text { Boxing }\end{array}$ & 3 kinds \\
\hline $\begin{array}{l}\text { Anderson } \\
\text { Silva }\end{array}$ & 8 & $\begin{array}{l}\text { Muay Thai, Box- } \\
\text { ing, Brazilian Jiu- } \\
\text { Jitsu,Taekwondo, } \\
\text { Judo, Capoeira }\end{array}$ & 6 kinds \\
\hline $\begin{array}{l}\text { Georges } \\
\text { St-Pierre }\end{array}$ & 8 & $\begin{array}{l}\text { Kyokushin, Muay } \\
\text { Thai,Boxing, } \\
\text { Wrestling,Brazilian } \\
\text { Jiu-Jitsu, Gaidojut- } \\
\text { su }\end{array}$ & 6 kinds \\
\hline
\end{tabular}

Table 3 shows that Randy Couture and Matt Hughes have a technique style of four species and three species, Anderson Silva and Georges St-Pierre have six kinds. Therefore we can learn that UFC champions who have won maximum times have a variety of different types of technique style; the integration of various types of fighting techniques is an important condition for MMA ability. 


\subsection{Distribution of Technique Style in the Training of 20 UFC Champi- on}

Fighting martial is an ancient skill. In the evolution process of nature, humans being cannot survive without the help of fighting ability. Every nation in the world has its own unique fighting skills which have a unique technique style and different technique style has different martial effect. In order to know the frequency of technique style in the training of UFC champion, we calculated the times one technique species are used in the training of 20 UFC champion. (Table 4).

Table 4 Times of Technique Species Used of 20 UFC champion

\begin{tabular}{|c|c|c|}
\hline TIMES & TECHNIQUE SPECIES & KINDS \\
\hline 15 & Wrestling & 1 \\
\hline 13 & Brazilian Jiu-Jitsu & 1 \\
\hline 12 & Boxing & 1 \\
\hline 8 & Muay Thai & 1 \\
\hline 7 & Karate & 1 \\
\hline 6 & Taekwondo & 1 \\
\hline 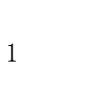 & $\begin{array}{l}\text { Judo 、 Sambo 、 Freestyle } \\
\text { Fighting 、 Submission Grap- } \\
\text { pling、Gaidojutsu、 Capoeira }\end{array}$ & 6 \\
\hline TOTAL & & 13 \\
\hline
\end{tabular}

(Table Remarks: According to technique characteristics, wrestling will stand for greco-roman wrestling, catch wrestling, submission wrestling and freestyle wrestling; karate will stand for kenpō karate, koei-kan karate, kyokushin, machida karate and shotokan karate; taekwondo will stand for kickboxing in this paper.)

Table 4 tell us that in the 20 UFC champion, wrestling (including the grecoroman wrestling, freestyle wrestling, catch wrestling and submission wrestling and other kinds of wrestling) is the most popular technology which is learned by fifteen players, followed by Brazilian JiuJitsu, boxing, muay Thai, karate, taekwondo, respectively $13,12,8,7$ and 6 ; judo 、 sambo 、 freestyle fighting 、 submission grappling 、 gaidojutsu 、 capoeira are one.

\section{References}

[1] Li Jilin. Analysis of the Use of Techniques in 2011 Ultimate Fighting Competition [J]. Fighting - Martial Science, 2012, 9 (3):83 -84, 101.

[2] Yang Dianli, Qiu Zhenqiang, Ding Hongwei. The Study of Winning Strategy for Chinese Martial Sanda Athletes in the K-1 Game [J]. Fighting - Martial Science, 2009,6 (3) :54- 56.

[3] Liu Mingliang, Gao Jing. Comparison and Contrast of Sports Culture of Chinese Sanda and American MMA [J]. International Relations Institute Journal, 2010 (3) :98- 102.

[4] Hu Zurong, Wang Daojie, Yang Mingming. Study On Chinese Sanda Athletes Start Training of "Other Fighting Projects [J]. Capital Institute of Physical Education, 2011,23 (3) $: 255-258$.

[5] Liu Mingliang, Yin Zhao. Comparison and Contrast Research on Chinese Martial Arts and American Ultimate Fighting Techniques [J]. Fighting - Martial Science, 2010,7 (7) :55- 56.

[6] Yu Wanling. Development Theory of Sanda [J]. Sports Culture Guide, 2010 (1):102- 105

[7] Wang Peikun. Thinking of Chinese Sanda Entering the World Sports [J]. Sports Science, 2010, 14 (1): 28- 31.

[8] Jiang Chuanyin. Development and Countermeasures of Chinese Martial Art Sanda [J]. Shanghai Sports University Journal, 2010, 34 (5):54- 57.

[9] Li Quansheng. Problems and Development Studies of Chinese Martial Arts League (WMA)[J]. Chinese Martial Art Research, 2011, 1 (3) :19 $-21,24$.

[10] List of UFC champions[EB/OL].Wikipedia,[2011-0706].Http://en.wikipedia.org/wiki/List _of_UFC_champions. 